\section{BESPOKE COMMERCIAL LOANS}

Wesleyan Bank, part of Wesleyan Assurance Society, is launching a bespoke commercial loan service in response to demand from dentists. Wesleyan provides specialist financial advice and services to dentists, doctors, lawyers and teachers.

Wesleyan Bank's loans service is backed by an in-depth knowledge of the needs of dental practices, which means Wesleyan has a clearer understanding of why a loan is required. Wesleyan Bank provides loans so dentists can modernise surgeries and buy new equipment, to support dentists wanting to buy a practice or those wishing to expand and buy a new surgery. Wesleyan also provides short-term loans to help with personal tax bills, a model that has proven extremely successful with legal customers.

For more information about Wesleyan Bank commercial loans for dentists visit www.wesleyan. co.uk/dentistcommercial.

\section{EVERYTHING YOU NEED TO SUCCEED}

Apolline offers tailored, practical business support to dental practices allowing you to get back to what you do best.

Apolline offers support with your management processes, your business development and HR issues, your compliance and your KPIs - everything your practice needs to succeed.

Apolline's patient and staff satisfaction surveys and analysis will provide a detailed round up of feedback data. Apolline workshops are held twice a year and cover compliance related subjects and important training courses.

Call Apolline for business advice on 01142096250 or visit www.apolline.uk.com.

\title{
EVEN MORE FINANCIAL SUPPORT FOR DENTISTS
}

As the lowest cost (DPAS vs. competitor standard adult patient charges 2013) option of the three major dental plan providers for practices with reasonable numbers of patients on plan, DPAS has always made financial sense for dentists, but the recent launch of DPAS Solutions 'Voucher Rewards' has further enhanced the company's support for dentists in this area.

The scheme offers practices switching from competitor providers to their own DPAS-supported plans a $£ 10$ voucher for every patient successfully transferred over a six-month period, which can then be used to acquire the external expertise that they believe will be of most benefit to their practice. Quite simply, this means that a practice with 1,500 patients on plan stands to receive up to $£ 15,000$ to spend on any additional services that they choose.

Vouchers can be used on compliance consultancy, marketing and PR, websites, business management and even finance, offering each practice the flexibility to choose the services that they feel will best support the growth of their business.

To find out exactly how much your move to DPAS could be worth, call 01747870910 or visit www.dpas.co.uk.

\section{ADVICE ON THE INS AND OUTS OF FINANCE}

Access to the very best advice is indispensable when making any professional move. Enlisting the help of money4dentists will mean that when making any financial decision you have access to advice from a team of specialist Independent Financial Advisers who know the ins and outs of dental finance.

The future is unpredictable and illness or injury may cause an income deficit. However, with the help of money4dentists you can choose an income protection plan that will be perfect for you, allowing you the peace of mind that should anything go wrong, you and your family will remain stable.

\section{A RADIANT NEW DENTAL PLAN}

National Dental Plan Ltd (NDP), one of the largest providers of corporate dental plans in the UK, has announced the launch of a new and enhanced proposition which includes a percentage-reimbursement product called 'Radiant'. The new product, which provides 100\% reimbursement for preventative and minor treatments and $80 \%$ for major treatments (subject to tCtc's), goes live for businesses on 2 September 2013 and is introduced following a major review of current market trends and customers' needs. It complements NDP's existing product, Clear, which provides a fixed level of reimbursement (subject to tetc's).

Radiant includes an option for employers to offer bespoke cover alongside five core options which have different pricing levels and benefits. Employers will be able to mix and match the exact levels of cover to create their own unique corporate
With more than 16 years' experience providing fiscal advice to dental professionals, money4dentists know every financial concern that those in the dental industry face, so you can be sure that they can help you with advice that is tailored to fit your exact needs.

For more information call 0845345 5060, email info@ money4dentists.com or visit www.money4dentists.com. plans, according to the demographics of their employee base.

As part of NDP's enhanced proposition, a high number of benefits come as standard, including child orthodontics and mouth guards. NDP is committed to providing choice for employees and continues to offer cover for treatment by any dentist, anywhere in the world. In addition, NDP is also making it easy for employers to switch schemes by providing cover for pre-existing conditions (including planned and pending treatment) with no waiting periods when transferring.

To find out more visit www. nationaldental.co.uk. 